\title{
Ойратский литературный сборник из фондов Национального музея Тувы"
}

\author{
Баазр А. Бичеев \\ Калмыцкий научный центр Российской академии наук, Российская Федерация \\ Каадыр-оол А. Бичелдей \\ Национальный музей им. Алдан-Маадыр Республики Тыва, Российская Федерация
}

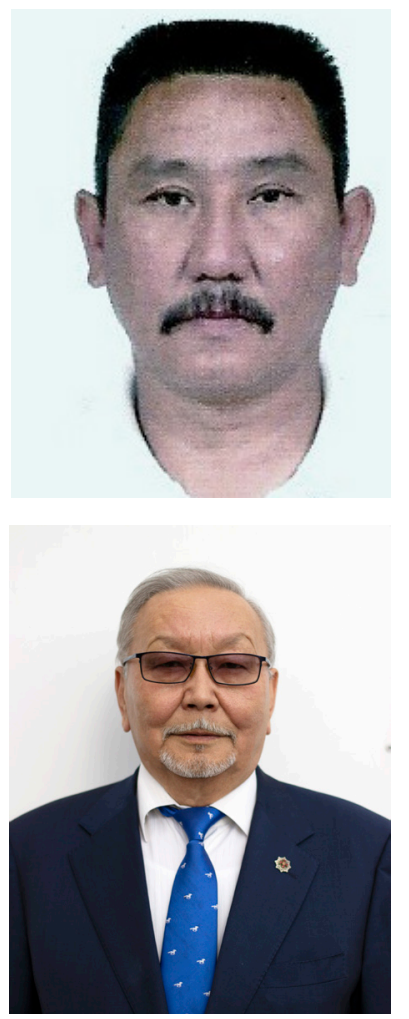

В статье вводится в научный оборот текст ойратского литературного сборника из фондов Нациионального музея им. Алдан-Маадыр Республики Тыва. Это единственный известный список ойратского сборника, в который вошли два широко известных произведения, относящихся к одному виду литературы - поучения или наставления (сургаал), - но отличающихся своим содержанием.

Первый текст - небольшое по своему объему произведение, в котором через диалог Будды и брахмана раскрывается квинтэссенция буддийского учения. Повесть известна под несколькими названиями, в том числе и как «Повесть о Будде и брахмане». Текст этой повести известен только на «ясном письме» и в настоящее время нет данных о его существовании на старомонгольской графике.

Второе произведение - широко известная в старописьменной монгольской литературе «Повесть о мальчике на черном быке». В ойратской литературе «ясного письма» текст известен под названием «Повесть о трехлетнем мальчике».

Приводится транслитерация ойратского текста с параллельным переводом на русский язык и комментариями.

Ключевые слова: ойратская литература; литературный сборник; ясное письмо; буддийская литература; Национальный музей Республики Тыва; Тува

" Исследование проведено в рамках государственной субсидии - проект «Устное и письменное наследие монгольских народов России, Монголии и Китая: трансграничные традиции и взаимодействия» (регистрационный номер АААА-А19-119011490036-1).

Бичеев Б. А., Бичелдей К. А. Ойратский литературный сборник из фондов Национального музея Тувы [Электронный ресурс] // Новые исследования Тувы. 2019, № 4. URL: https://nit.tuva.asia/nit/article/view/883 (дата обращения: дд.мм.гг.). DOI: 10.25178/nit.2019.4.5

Бичеев Баазр Александрович - доктор философских наук, ведущий научный сотрудник отдела монгольской филологии Калмыцкого научного центра Российской академии наук. Адрес: 358000, Россия, г. Элиста, ул. И. К. Илишкина, д. 8. Тел.: +7 (84722) 3-55-06. Эл. адрес: baazr@mail.ru ORCID ID: 0000-0002-9352-7367

Бичелдей Каадыр-оол Алексеевич - доктор филологических наук, профессор, директор Национального музея имени АлданМаадыр Республики Тыва. Адрес: 667000, Россия, г. Кызыл, ул. Титова, д. 30. Тел.: +7 (394-22) 2-28-04. Эл. адрес: bka.hural@ mail.ru ORCID ID: 0000-0002-6754-7794

Bicheev Baazr Alexsandrovich, Doctor of Philosophy, Leading Research Associate, Department of Mongolian Philology, Kalmyk Scientific Center of the Russian Academy of Sciences, Postal address: 8 Ilishkin St., Elista 358000 Russian Federation. Tel.: +7 (84722) 3-55-06.Email: baazr@mail.ru

Bicheldey Kaadyr-ool Alexeevich, Doctor of Philology, Professor, Director, Aldan-Maadyr National Museum of the Republic of Tuva. Postal address: 30 Titov St., 667000 Kyzyl, Russian Federation. Tel.: +7 (394-22) 2-28-04. E-mail: bka.hural@mail.ru 


\title{
An Oirat literary collection from the Aldan-Maadyr National Museum of the Tuva Republic
}

\author{
Baazr A. Bicheev \\ Kalmyk Scientific Center of the Russian Academy of Sciences, Russian Federation, \\ Kaadyr-ool A. Bicheldey \\ Aldan-Maadyr National Museum of the Tuva Republic, Russian Federation
}

\begin{abstract}
The article introduces into scientific discourse the text of one Oirat literary collection contained in the Aldan-Maadyr National Museum the Tuva Republic. This is the only known manuscript copy of the Oirat collection which includes two famous works related to the same literary genre - precepts or instructions (Mong. cypzaar) - though essentially different.

The first text is a small work which reveals a quintessence of the Buddhist teaching through a dialogue between the Buddha and a Brahmin. The story is referred to under different names, including as 'The Tale of the Buddha and the Brahmin'. The text of this novel is known in its Clear Script version only, and currently there is no data regarding any Classical Mongolian versions.

The second work is widely known in Old Mongolian literature as 'The Tale of the Boy Riding the Black Bull'. In Oirat Clear Script literature, the text is known as 'The Tale of the Three-Year-Old Boy'.

The article provides a transliteration of the Oirat text accompanied by a Russian translation and respective comments.
\end{abstract}

Keywords: Oirat literature; literary collection; Clear Script; Buddhist literature; National Museum of the Tuva Republic; Tuva

" The reported study was funded by government subsidy - project name 'Oral and Written Heritage of the Mongolic Peoples of Russia, Mongolia and China: Cross-Border Traditions and Interactions' (registration number AAAA-A19-119011490036-1).

\section{For citation:}

Bicheev B. A. and Bicheldey K. A. An Oirat literary collection from the Aldan-Maadyr National Museum of the Tuva Republic. The New Research of Tuva. 2019, no. 4 [online] Available at: https://nit.tuva.asia/nit/article/view/883 (access date ...). DOI: $10.25178 /$ nit.2019.4.5

\section{Введение}

В старописьменной ойратской литературе известны сборники, которые составлялись из наиболее известных и широко распространённых произведений. Иногда они имели смешанный характер, когда литературные сочинения могли соседствовать с фольклорными, обрядовыми и астрологическими текстами. Некоторые из них состояли всего лишь из двух произведений небольшого объема, т. е. того минимального количества произведений, которое позволяет определять их как литературный сборник. Другие - включали несколько текстов достаточно большого объема.

К примеру, сборник под шифром $\mathbf{E} 90$ из ойратской коллекции Института восточных рукописей РАН состоит из шести известных произведений ойратской литературы - «История субургана Джаронхашур», «Повесть о царевиче Го-чихэту», «Субхашита», «Повесть об Усун-Дэбискерту-хане», «Поучения Чингис-хана» и собрания буддийских наставлений (Сазыкин, 1988: № 425). Этот литературный сборник представляет собой калмыцкую рукописную книгу в форме сшитой тетради европейского образца достаточно большого размера (32,5 х 20 см.) и объема (130 с.). Книги такой формы стали появляться среди калмыцких рукописей только в самом начале XIX вв. Они были не очень удобны для хранения при кочевом быте и могли появиться лишь после появления первых стационарных поселений, строительства деревянных, а затем и каменных хурулов, позволяющих хранить такие книги.

Образцы литературных сборников присутствуют во всех известных отечественных коллекциях ойратских рукописей (Сазыкин, 1988: № 2170, № 2171, № 2178; Uspensky, 1999: № 428). В том числе и среди восьми рукописей, написанных ойратским «ясным письмом» и хранящихся в Национальном музее им. Алдан-Маадыр Республики Тыва. Этот литературный сборник, хранящийся под шифром 
M-659/834, состоит из двух небольших по своему объему, но широко известных в старописьменной ойратской (калмыцкой) литературе произведений - «Повесть о Будде брахмане» («Бурхн багш бирмн хойр») и «Повесть о трехлетнем мальчике» («Гurban nasutu kü̈̈keni touji orošiboi»).

А. Г. Сазыкин пишет, что большинство ойратских рукописей тувинской коллекции позднего происхождения - не ранее начала XIX столетия и только вышеуказанный сборник может быть отнесен $\mathrm{K}$ XVIII в. (Сазыкин, 1992: 45). Точные сведения о данном рукописном сборнике из фонда тувинского музея следующие:

\section{M-659/834}

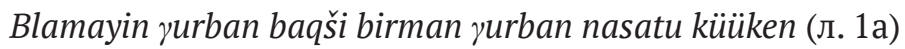

1. Burxan baqši birman xoyorin tuuji (л. 1b-3b).

«Повесть о Будде и брахмане».

2. Гurban nastu kü̈̈keni touji (л. 3b-л. 9b)

«Повесть о трехлетнем мальчике»

Ойратская рук., 9 л. 22 х 8.5, 21 стк., черная и красная тушь (Sazykin, 1994: 370).

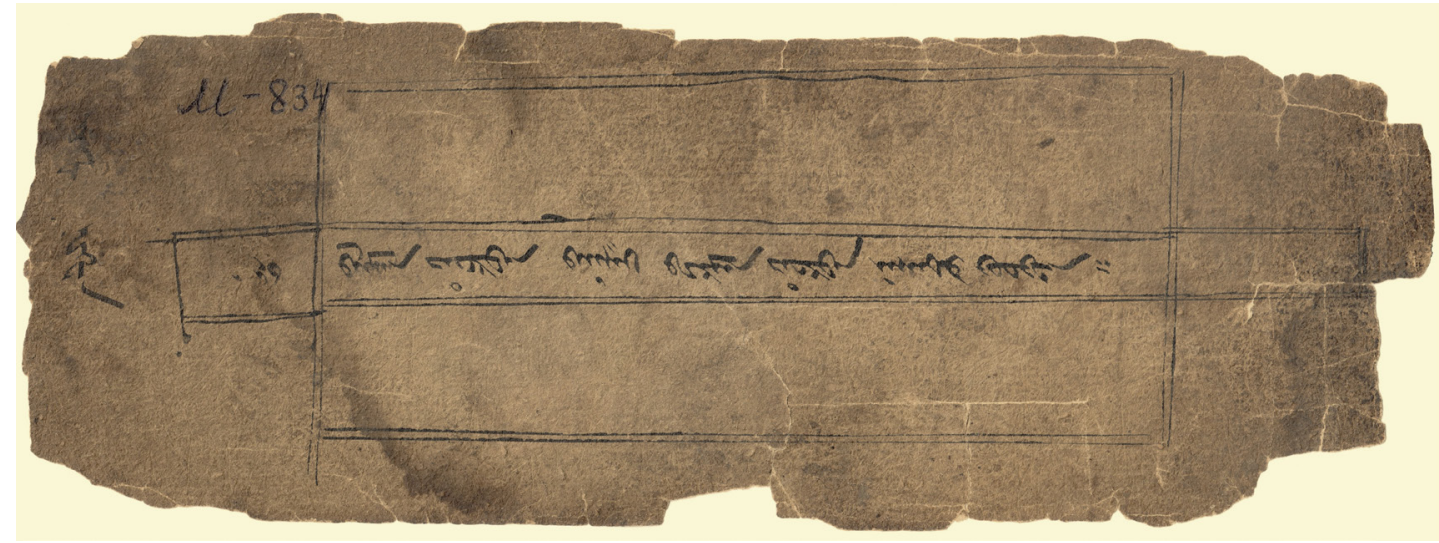

Фото 1. Титульный лист 1а. рукописи М-659/834 «Повести о Будде и брахмане».

Из фонда Национального музея им. Алдан-Маадыр Республики Тыва.

Photo 1. Page 8b. of the manuscript M-659/834 «The story of Buddha and Brahman».

From the collections of the Aldan-Maadyr National Museum of the Republic of Tuva.

Ойратские рукописные сборники, как правило, не имеют общего названия. Но на титульном листе


названии один текст «Повесть о трехлетнем мальчике» («Гurban nasutu kü̈̈keni touǰi orošiboi») определяется достаточно легко - «үurban nasutu kü̈̈keni». А вот другой текст «Повесть о Будде брахмане» («Бурхн багш бирмн хойр») был известен под разными названиями, а потому составитель сборника указал опорные во всех известных названиях слова - «baqši birman» (Будда и брахман). Первые два слова названия «Blamayin yurban» (букв. Учителю-наставнику, Трем) - это слова, вырванные из традиционной формулы выражения почитания Учителю-наставнику и Трем драгоценностям.

\section{Списки рукописей «Повести о Будде брахмане»}

«Повесть о Будде брахмане» пользовалась особой популярностью среди простых верующих, несмотря на его философское содержание. Н. Очиров в своих отчетах о поездке к Астраханским калмыкам летом 1909 и 1911 гг., г., в числе рукописей, приобретенных им для библиотеки Санкт-Петербургского университета, называет два списка этого текста - «Повесть о Будде и брахмане» («Бурхн-багш бирмн хойрин тууж») (Очиров, 1910: 74) и «Будда и брахман» («Бурхн багш, бирмн») в составе литературного сборника (Очиров, 1913: 90).

Текст этой повести вошел в «Калмыцкую хрестоматию для чтения в аймачных и в младших отделениях школ», составленную учителем народной школы Шургучи Болдыревым из наиболее известных текстов старописьменной калмыцкой литературы. Учебник был подготовлен к печати в 1905 г., но в 
силу сложившихся обстоятельств был напечатан лишь в 1927 г. представителями калмыцкого зарубежья (Хонхо, 1927: 111-113).

В отечественных и зарубежных центрах хранения монгольских рукописей выявлено семь ${ }^{1}$ списков этого текста на «ясном письме». Один текст (M-659/834) в составе литературного сборника, как уже было указано выше, хранится в Национальном музее им. Алдан-Маадыр Республики Тыва. Второй список, в составе другого литературного сборника, состоящего из десяти произведений, хранится в коллекции ойратских рукописей Научной библиотеке им. М. Горького по направлению востоковедение Санкт-Петербургского государственного университета:

428. Calm A-15. Коллекция Голстунского (1857),

Сказки на калмыцком языке (л. 1a)

1. Dayiči dalan xoyor tenggeriyin ölbē jlba abadaq dalai očir xāni... (л. 2a)

2. Гunun xara Arvā-yin tuuli (л. 4a)

3. Uxāta birmani tuuj̆i dousbā (л. 9b)

Ойр. рук., тетрадь, лл. 1-29+ 1 л., 22 х 18, 14-20 стк.

Сборник из 10 разных текстов.

(Uspensky, 1999: № 428).

Два текста находятся в коллекции ойратских рукописей Саксонской государственной библиотеки (Sächsische Landesbibliothek - Staats - und Universitätsbibliothek Dresden). На титульном листе одной рукописи вместо названия воспроизведены слова первой строки произведения:

Verz. 487. Msc. Dresd. Eb. $405^{\mathrm{b}}-\mathrm{m}$. LB, Drezden

Buddhalegende (kalm.).

Blama-luүā ilyal ügei Burxan baqšiyin [л. 1a].

Учителю-наставнику неразличимого с Буддой...

Ойр. рук., 4 л., 8 x 22, 23-24 стк.,

Плотная зеленая русская бумага, чернило, перо.

Транслитерация текста и факсимиле этой рукописи опубликовано в сборнике статей «Мир “ясного письма"» (Санджиев, 2010).

Второй ${ }^{2}$ список не имеет названия и представляет собой копию с первого списка:

504 Ms. or. oct. 418. WdtB, Marburg (ehem. PrSB)

d. Buddhalegende (Titel fehlt im Drezden Original),

Копия рук. Dresd. Eb. $405^{\mathrm{b}}-\mathbf{m}$.

Ойр. рук., 4 л., 20 стк.

(Heissig, Sagaster 1961: 504d).

Некоторые ойратские тексты из этой коллекции - это копии, выполненные И. Иеригом (1747-1795) с калмыцких рукописей. Живя в немецкой колонии Сарепта (близ г. Царицына), он выучил калмыцкий язык, освоил «ясное письмо» и тибетскую письменность с помощью калмыцких лам. За время своего пребывания у калмыков И. Иериг собрал сведения об их быте и религии, сделал переводы на немецкий язык калмыцких сказок, приобрел оригиналы, а также выполнил копии с некоторых редких рукописей. Все эти материалы были переданы им в Академию наук, где он служил в качестве переводчика (Шафрановская, 1965).

Еще три списка «Повести о Будде и брахмане» находятся в Монголии. Одна рукопись хранится в Доме-музее академика Ц. Дамдинсурэна в г. Улан-Батор (Монголия):

№ 243. (220) A5-37 (MH-598)

Doqšin birman-ni tииј̈ (л. 1a).

Притча о гневном брахмане.

\footnotetext{
${ }^{1}$ Копия еще одного неполного списка этого текста, обнаруженная у одного из жителей Калмыкии, хранится в личном архиве Б. А. Бичеева. Есть неподтвержденные данные о существовании списков этой повести в личных коллекциях ойратов Синьцзяна в Китае.

${ }^{2}$ Копии двух этих рукописей хранятся в Научной библиотеке им. П. Э. Алексеевой Калмыцкого научного центра РАН (Инв. ном. 49262, 40242).
} 
Ойр. рук., 4 л., 26 × 8, 20 стк., китайская бумага, черная тушь, калам.

(Билгүүдэй, Отгонбаатар, Цендина, 2018: 195).

Второй текст находится в библиотеке монастыря Рашигончелинг, расположенного недалеко от города Ховд в Западной Монголии:

\section{Barintag-01-11}

Doqšin birimini touǰi orošibo (л. 1a).

Притча о гневном брахмане.

Ойр. рук., 3 л., 33.8 х 7.9, 20 стк., плотная пожелтевшая бумага, черная и красная тушь, калам.

Третья рукопись также хранится в Западной Монголии в рукописном фонде Ховдского государственного университета:

Doqšin birman-ni tuuji orošiboi

Ойр. рук., 4 л., 28 × 8, 20 стк.,

черная тушь, калам.

(Ганболд, 2005: 86).

В 2005 г. текст этого списка был опубликован современной монгольской графикой в сборнике «Ою чихт хөвүүний тууж тэргүүтэн монголын сонгодог уран зохиолын хэдэн дурсгал» (там же: 86-87).

Все известные списки «Повести о Будде и брахмане» можно разделить на два варианта - основной и дополненный. В основном варианте содержится текст самой повести. В дополненном варианте к нему добавлено приложение, в котором приведены назидательные наставления, извлеченные из другого сочинения. Из семи вышеуказанных текстов к основному варианту относятся три рукописи:

1. A5-37 (МН-598) из Дома-музея академика Ц. Дамдинсурэна;

2. Calm A-15 из Научной библиотеке им. М. Горького по направлению востоковедение СПбГУ;

3. М-659/834 из фондов Национального музея им. Алдан-Маадыр Республики Тыва.

Основная часть всех семи рукописей одинакового содержания. Все различия сводятся к разному написанию, перестановке местами или замене некоторых слов на другие. Такие разночтение, как правило, являются результатом уровня грамотности переписчика текста.

Этот небольшой по объему текст, построенный на диалоге между Буддой и брахманом, в сконцентрированном виде излагает основные положения буддийского учения. В экспозиции произведения поведано о том, что Будда, с монашеской чашей в руке, подошел за подаянием к одному дому и постучал в дверь. На его стук вышел домовладелец - высокомерный и вспыльчивый брахман. Увидев буддийского монаха, он сразу же бросает ему своеобразный вызов в виде трудных вопросов. В своих ответах Будда акцентирует внимание оппонента как на отрицательные качества, изначально присущие самой природе человека, так и на те качества, которые взращиваются человеком его собственными усилиями и связаны с благими установками сознания.

Центральный аспект буддийского воззрения - учение о карме - занимает главное положение в содержании этого диалога. Регламентация поведения вытекает из необходимости выбора своей будущей участи, из представления об универсальной силе учения, из желания вырваться из круговорота сансары.

Брахман спросил:

- Монах-тойн, что не сожет огонь,

Не растворит вода, не украдет вор?

Что не сможет потребовать властелин,

Что не сможет отобрать силой враг?

Будда ответил:

О, брахман, результаты содеянных благих и греховных деяний

${ }^{1}$ http://www.dlir.org/archive/items/show/11326 (дата обращения: 10.04.2019). 
Не сожжет огонь, не растворит вода, не украдет вор.

Не сможет отобрать силой властелин, и даже враг.

В этом и будущих рождениях результаты этих двух деяний будут

сопровождать тебя подобно тени.

Повесть заканчивается сентенцией о том, что брахман, потрясенный услышанными из уст Будды словами, последовал за ним, и вскоре достиг святости архата'

\begin{tabular}{|c|c|c|c|}
\hline № & Транслитерация ойратского текста ${ }^{2}$ & № & Русский перевод \\
\hline 1 & $\begin{array}{l}\text { [1a] Blamayin yurban baqši birman yurban } \\
\text { nasatu küüken:: }\end{array}$ & 1 & $\begin{array}{l}\text { [1a] Ламы }{ }^{4} \text { три; Будда [и] брахман; Трехлетн- } \\
\text { ий мальчик. }\end{array}$ \\
\hline 2 & 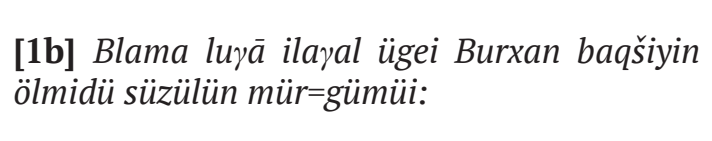 & 2 & $\begin{array}{l}\text { [1b] C благоговением припадаю к стопам } \\
\text { Будды, неразличимого с Учителем-настав- } \\
\text { ником! }\end{array}$ \\
\hline 3 & $\begin{array}{l}\text { Urida nigen caqtu Bur=xān badir bārüi nigen } \\
\text { geriyin öüden-dü kürün duldui küdölgü=küyidü: } \\
\text { tere geriyin ezen burui nomtoi doqšin abiritei } \\
\text { yeke omoqtoi birman yarači irēd eyin ögüülebei: }\end{array}$ & 3 & $\begin{array}{l}\text { Как-то раз в прежние времена Будда, с чашей } \\
\text { для подаяния }{ }^{5} \text { в руке подошел к одному дому } \\
\text { и постучал в двери монашеским посохом }{ }^{6} \text {. } \\
\text { [На стук] вышел хозяин дома - гневный } \\
\text { нравом, высокомерный иноверец брахман и } \\
\text { [увидев буддийского монаха] спросил: }\end{array}$ \\
\hline 4 &  & 4 & $\begin{array}{l}\text { «Монах-тойн }{ }^{7} \text { что может ранить глубже, чем } \\
\text { острый меч? Что может отравить больше, чем } \\
\text { яд? Что может обжечь сильнее, чем огонь? } \\
\text { Что может быть темнее, чем ад?» }\end{array}$ \\
\hline 5 & 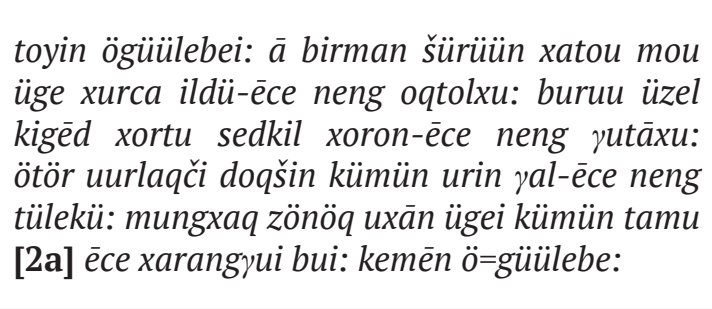 & 5 & $\begin{array}{l}\text { Монах-тойн ответил: «О, брахман, грубое, } \\
\text { резкое слово ранит глубже, чем острый меч. } \\
\text { Неправедное воззрение и зловредный ум } \\
\text { отравят больше, чем яд. Гнев вспыльчивого } \\
\text { человека обжигает сильнее, чем огонь. Ум } \\
\text { глупого, невежественного человека [2a] тем- } \\
\text { нее, чем ад». }\end{array}$ \\
\hline 6 & $\begin{array}{l}\text { birman asaqba: toyin yambar youman } \\
\text { mindasun-ēce jōolön: yambar youman aršān- } \\
\text { ēce amtatai: yambar youman zandan modun- } \\
\text { èce serüün: yambar you=man narani gerel-ēce } \\
\text { yeke gerelte=yi kemēen asaqba: }\end{array}$ & 6 & $\begin{array}{l}\text { Брахман спросил: «Монах-тойн, что может } \\
\text { быть мягче хлопковой ваты? Что может быть } \\
\text { слаще, чем нектар-амрита7? Что может дать } \\
\text { прохладу больше, чем тень сандалового } \\
\text { дерева? Что может быть ярче солнечного } \\
\text { света?» }\end{array}$ \\
\hline
\end{tabular}

\footnotetext{
${ }^{1}$ Архат (санск. arhant; тиб. dgra-bcom-pa; ойр. dayini daruqsani) - букв. Победивший своих внутренних врагов. В буддизме махаяны одна из ступеней достижения просветления. Один из эпитетов Будды.

${ }^{2}$ Транслитерация выполнена по рукописи М-659/834 из фондов Национального музея им. Алдан-Маадыр Республики Тыва. В транслитерации текста использованы следующие условные знаки: знак равенства = ставится в месте переноса части слова на другую строку в рукописи; в квадратные скобки [ ] заключены восстановленные буквы или слова. Слова, написанные в рукописи красной тушью, выделены подчеркиванием.

${ }^{3}$ В тексте перевода в квадратные скобки заключены слова дополняющие перевод, но отсутствующие в тексте рукописи.

4 Лама (санск. guru; тиб. bla ma; ойр. blama) - Гуру, Учитель-наставник.

${ }_{5}^{5}$ Чаша для подаяния (санскр. pātra; тиб. btsung-ba; ойр. badir) - монашеская чаша для сбора подаяния.

${ }^{6}$ Монашеский посох (санскр. khakhara; ойр. duldui) - деревянный посох с 12 железными кольцами, символизирующими

12 звеньев причинно-зависимого существования.

${ }^{7}$ Тойн (санск. śramana; тиб. btcung-ba; ойр. toyon) - монах высокого происхождения.
} 
toyin ögüü=lebe: $\bar{a}$ birman jōlön sayin $\ddot{u}=g e i$ mindasun-ēce jōlön: maši süzülün sonosxu sayin sedkil aršān-ēce amtatai: amuriliqsan sayin sedkil zandan modun-ēce serüün: tögüs erdemtei suryān čidaqči blama baqši narani gerel- $\bar{e}=c e$ yeke gereltei bui kemēn ögüüle=be:

birman asaqba: toyin yambar youman $\gamma$ aldu ülü

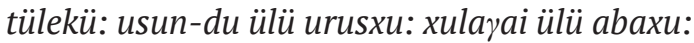
erketen üzēd küči-bēr ülü abaxu: dayisun čü abun ülü čidaxu kemēn [2b] asaqba:

toyin ögüülebe: $\bar{a}$ bir=man aliba üyiledüqsen sayin mou üyileyin ači üre yaldu ülü tülekü: usun-du ülü urusxu: xula үai ülü abaxu: erketen ezēd küči-bēr ülü abaxu dayisun čü abun ülü čidxu: ene xoyitu xoyor-tu ene xoyor üyile beyeyin sö̈̈der metü xoyino-ēce daxān odxu bui kemēn ögüülebe:

birman asaqba: to=yin ene yazar delekeyigi kēn ezelen barixu youn-du šütüji axu kēn eb=dükü: ken urubuulxu kemèn asaqbai:

toyin ögüülebe: $\bar{a}$ birman ene yazar delekeyigi möngkü-bēr bariqči mungxaq: ezelen barixu šütün bari=lduqsan-ēce bütün: tede möngkü ügeyin tula ebderekü urbaxu bui kemēn ögüülebe:

birman asaqbai toyin öqligüdü ali öqligü dé=dü: buyan-du ali buyan dēdü: $m o ̈ r=[3 \mathbf{a}]$ tü ali mör dēdü: amu=youlang-du ali amuyoulang dēdü: kemēn asaqba:

toyin ögüülebe à birman öqligüdü nomiyin öqligü-ēce dēdü ügei: buyan-du amitan-ni tusa üyiledküi-ēce dēdü ügei: mör-tü ar=ban züyil sayin yabudal-ēce dēdü ügei: amuroulang$d u$ burxani oron-du töröqsön-ēce dēdü amuroulang ügei bui kemèn ögüülebe:
Монах-тойн ответил: «О, брахман, доброе, ласковое слово мягче хлопковой ваты. Благоговейное желание слушать Учение слаще, чем нектар-амрита. Ум, успокоенный Учением, дает прохладу больше, чем тень сандала. Мудрый Учитель-наставник освещает [путь] ярче, чем солнечный свет».

Брахман спросил: «Монах-тойн, что не сожжет огонь, не растворит вода, не украдет вор? Что, увидев, не сможет отобрать силой властелин и не сможет забрать даже враг?» [2b]

Монах-тойн ответил: О, брахман, результаты содеянных тобой благих и грешных деяний не сожжет огонь, не растворит вода, не украдет вор, не сможет отобрать силой властелин и не сможет забрать даже враг. В настоящем и будущем [рождениях] результаты двух этих деяний всегда будут сопровождать тебя подобно тени».

Брахман спросил: «Монах-тойн, кто будет властвовать этим миром? Во что будут верить? Что разрушится, что изменится?»

Монах-тойн ответил: «О, брахман, этим миром вечно будет властвовать невежество.

11 В силу причинно-следственной связи все не вечно, все будет разрушаться и [вновь] возникать.

Брахман спросил: «Монах-тойн, какое под12 ношение высшее? Из благодеяний, какое деяние высшее? Среди дорог, какой путь [3a] высший? Какое благоденствие высшее?»

Монах-тойн ответил: «О, брахман, нет подношения выше, чем подношение Учения. Нет благодеяния выше, чем деяния на благо живых существ. Нет пути выше, чем путь десяти благих деяний ${ }^{1}$. Нет благоденствия выше, чем рождение в стране будд».

\footnotetext{
${ }^{1}$ Десять благих деяний (ойр. arban caүān buyan) - 3 благих деяний тела (отречение от убиения живых существ, воровства, прелюбодеяния); 3 благих деяниям речи (отречение ото лжи, грубости, суесловия); 4 благих деяния ума (отречение от зависти, жадности, гордости и ереси).
} 


\begin{tabular}{|c|c|c|c|}
\hline 14 & $\begin{array}{l}\text { birman asaq=ba: toyin ebečin-dü ali e=bečin } \\
\text { kündü: gemšildü ali gemšil kündü: acān-du } \\
\text { ali acān kündü: emčidü ali emči dé=dü kemēn } \\
\text { asaqba: }\end{array}$ & 14 & $\begin{array}{l}\text { Брахман спросил: «Монах-тойн, какая бо- } \\
\text { лезнь самая опасная? Какое обвинение самое } \\
\text { тяжкое? Какой груз самый тяжелый? Среди } \\
\text { врачей, какой врач лучший?» }\end{array}$ \\
\hline 15 & $\begin{array}{l}\text { toyin ö=gü̈̈llebe: à birman nü̈̈l kilin=ce-ēce } \\
\text { kündü ebečin ügei:dēdü [orod kigēd] küčitündu } \\
\text { mou üge ögüüleküi-ēce kündü gemšil ügei: } \\
\text { [3b] süzüqteini ed edleküi-ēce kündü acān } \\
\text { ügei: burxān-ēce dēdü emči ügei: kemēn } \\
\text { ögüü=leleqsen-dü: }\end{array}$ & 15 & $\begin{array}{l}\text { Монах-тойн ответил: «О, брахман, нет бо- } \\
\text { лезни опаснее грехов. Нет обвинения тяжче, } \\
\text { чем обвинение будд. Нет груза тяжелее, [3b] } \\
\text { чем быть истинно верующим. Нет врача луч- } \\
\text { ше, чем Будда». }\end{array}$ \\
\hline 16 & $\begin{array}{l}\text { tere birmani sed=kil uyaran nomoyoroǰi } \\
\text { maši bayasun toyin bolun [darui=du] dai=ni } \\
\text { daruqsani xutuq olbu=yi:: : :: }\end{array}$ & 16 & $\begin{array}{l}\text { [От услышанных ответов] Брахман растро- } \\
\text { гался, сознание его успокоилось и, возра- } \\
\text { довавшись, он стал монахом-тойном и вско- } \\
\text { ре обрел святость архата. }\end{array}$ \\
\hline 17 & sarva mam ga lam & 17 & Да будет благоденствие! \\
\hline
\end{tabular}

\section{Списки рукописей «Повести о трехлетнем мальчике»}

Второй текст из литературного сборника, хранящегося в Национальном музее им. Алдан-Маадыр Республики Тыва - «Повесть о трехлетнем мальчике» («Гurban nastu kü̈̈keni touji orošiboi»). Произведение существует в двух версиях. В старописьменной монгольской литературе оно известно под следующими названиями - «Повесть о мальчике на черном быке» («Jayidan qar-a ere üker-tü köbegün-ü tuүuji orosiba»), «История Гууши-наставника» («Gü̈̈ši neritü bagsi-yin tuuji orošiba»), «Притча об Учителе и ученике» («Baysi šabi-yin üliger»). В монгольском фонде ИВР РАН хранится семь списков этого произведения. Четыре из них представлены в виде отдельных рукописей (Сазыкин, 1988: № 59, № 61, № 62, № 63), три текста входят в состав различных литературных сборников (там же: № 419 (2), № 420 (1), № 2176 (4)).

В свое время академик Ц. Дамдинсурэн опубликовал сводный монгольский текст этого произведения на основе нескольких списков (Damdinsürüng, 1959: 481-486).

Ойратская версия известна под названием «Повесть о трехлетнем мальчике» («Гurban nastu kü̈̈keni touji orošiboi»). Известно о пяти списках этого произведения на «ясном письме».

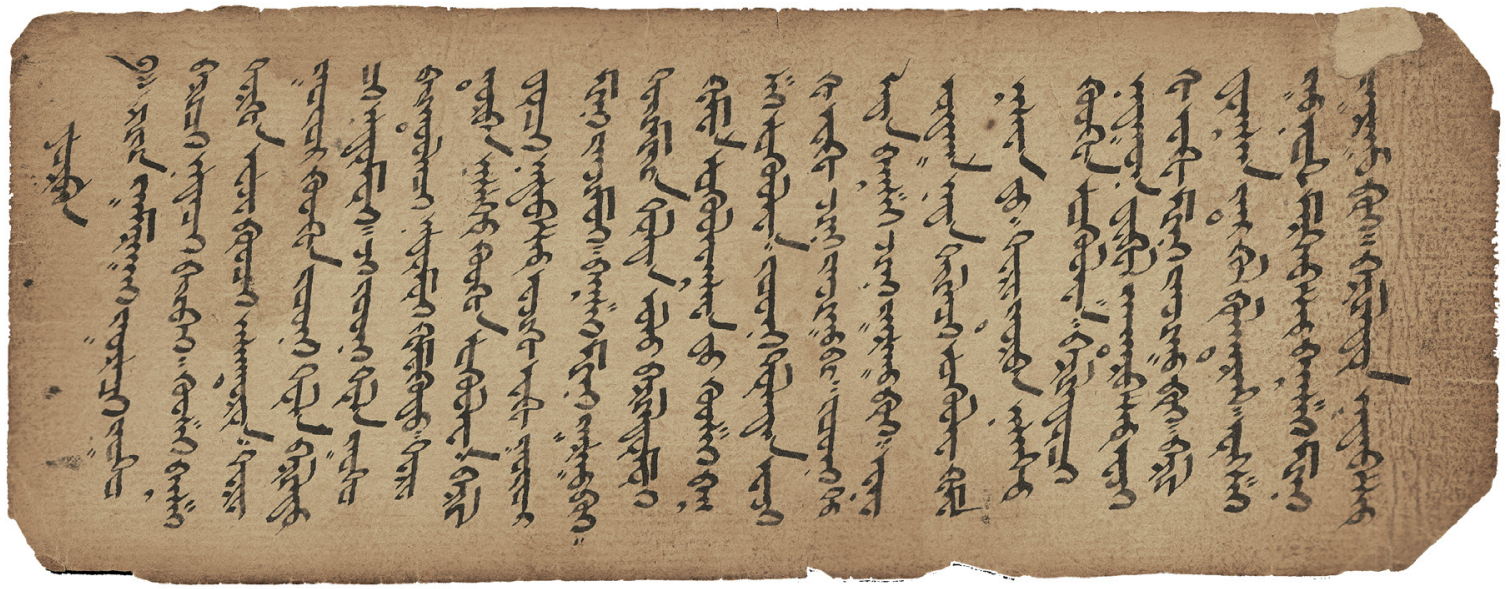

Фото 2. Лист 4а. рукописи М-659/834 «Повести о трехлетнем мальчике».

Из фонда Национального музея им. Алдан-Маадыр Республики Тыва.

Photo 2. Page 4a. of the manuscript M-659/834 "The story of three-year-old boy».

From the collections of the Aldan-Maadyr National Museum of the Republic of Tuva. 
Один текст (M-659/834) в составе литературного сборника из Национального музея им. Алдан-Маадыр Республики Тыва.

Второй список хранится в ойратской коллекции Института восточных рукописей РАН:

В 106 (IV коллекция Б. Я. Владимирцова).

Гurban nasutu kü̈̈ken-ni tuuǰ orošiboi [л. 1a]

Ойр. рук., 8 л., 22 × 9 (17 x 7,5), 18-19 стк.,

рус. бумага, чернила, перо.

(Сазыкин, 1988: № 60).

Три рукописи хранятся в Монголии. Один из них находится в рукописном фонде Ховдского государственного университета:

\section{ТоБ: № 95}

Гurban nasutu kü̈̈keni tuuǰ orošiboi

Ойр. рук., 10 л., 20 × 8.5, (16 x 6.5) 16-17 стк.,

черная тушь, калам.

(Ганболд, 2005: 82).

В 2005 г. текст этого списка был опубликован в современной монгольской графике в сборнике «Ою чихт хөвүүний тууж тэргүүтэн монголын сонгодог уран зохиолын хэдэн дурсгал» (там же: 82-85).

Другой список хранится в Доме-музее академика Ц. Дамдинсурэна в г. Улан-Батор:

\section{A5-32 (MH-593)}

Гurban nastu küükeni touǰ orošiboi:

Ойр. рук., 10 л., 22 х 8.6, 17-20 стк.,

кит. бумага (л. 9-10 рус. бумага),

красные и черные чернила, калам.

(Бильгүүдэй, Отгонбаатар, Цендина, 2018: № 303).

Третья рукопись находится в ойратской коллекции Институт языка и литература Академии наук Монголии:

Гurban nastu kü̈̈keni touji:

Ойр. рук., 4 л., 22 х 7.5, 17.5 x 6, 19-21 стк.,

красные и черные чернила, калам.

Рукопись не полная.

(Gerelmaa, 2005: № 303).

«Повесть о трехлетнем мальчике» в отличие от «Повести о Будде и брахмане» несколько больше по объему, но текст также выстроен в форме - «трудный вопрос - ответ».

В экспозиции говорится о том, что Учитель Гууши, погрузив в повозку книги, в сопровождении учеников отправился на поиски новых учеников. В одной местности он увидел трехлетнего мальчика, который строил домик из обломков поломанного кувшина.

Учитель Гууши, сойдя с повозки, спросил:

- Почему те двое мальчиков играют, борясь друг с другом, а ты строишь домик?

Тот трехлетний мальчик ответил:

- Если я стану бороться, то родители меня накажут, а учитель будет ругать меня. Поэтому я не борюсь с ними.

Учитель Гууши спросил:

- Объясни мне причину сказанного тобой. За что родители накажут тебя, и почему учитель будет ругать тебя?

Трехлетний мальчик ответил:

- Если, борясь, я порву одежду, то родители меня накажут. [К тому же] в борьбе можно вывихнуть руку или ногу. Если забуду про чтение книги, то учитель станет меня ругать. Борьба приносит физические страдания телу. Поэтому я играю, строя домик. 
Учитель Гууши, удивленный ответом мальчика, предлагает мальчику ответить на его трудные вопросы. Услышав его остроумные ответы, учитель предлагает ему стать его учеником. Мальчик отвечает ему отказом и сам в свою очередь озадачивает учителя трудными вопросами, на которые тот не может дать ответа. В финале произведения, признав свое поражение, учитель Гууши просит мальчика не говорить людям о его поражении и отправляется дальше вместе со своими учениками.

\begin{tabular}{|c|c|c|c|}
\hline No & Транслитерация ойратского текста & No & Русский перевод \\
\hline 18 & Om sav sadv: & 18 & Ом сав саду: \\
\hline 19 & 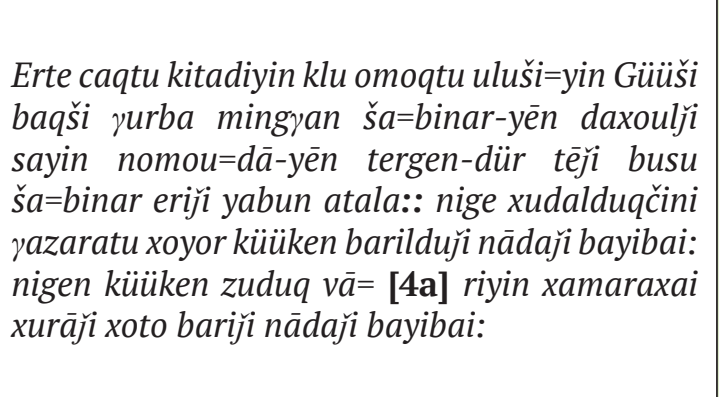 & 19 & $\begin{array}{l}\text { В прежние времена Учитель Гууши из ки- } \\
\text { тайского рода высокомерных лу1 в сопрово- } \\
\text { ждении трех тысяч своих учеников, погрузив } \\
\text { в повозку лучшие книги, отправился на пои- } \\
\text { ски других учеников. В одной торговой мест- } \\
\text { ности, он увидел, как двое мальчиков играя, } \\
\text { боролись друг с другом, а один мальчик, } \\
\text { играл черепками [4a] разбитого кувшина, } \\
\text { строя из них домик. }\end{array}$ \\
\hline 20 & 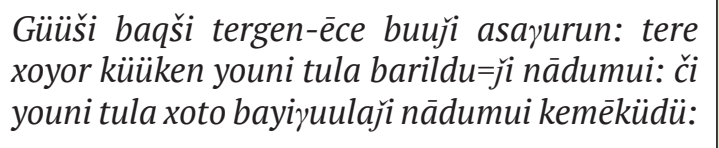 & 20 & $\begin{array}{l}\text { Учитель Гууши, сойдя с повозки, спросил [у } \\
\text { него]: «Почему те двое мальчиков играют, бо- } \\
\text { рясь друг с другом, а ты строишь домик?» }\end{array}$ \\
\hline 21 & 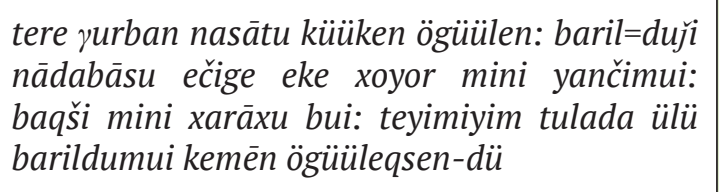 & 21 & $\begin{array}{l}\text { Тот трехлетний мальчик ответил: «Если я } \\
\text { стану бороться, то родители меня накажут, а } \\
\text { учитель будет ругать меня. Поэтому я не бо- } \\
\text { рюсь». }\end{array}$ \\
\hline 22 & $\begin{array}{l}\text { Gü̈̈̌š baq=ši ögü̈̈len: youni tulada eči=ge } \\
\text { eke čini yančixu bi: youni tu=lada baqši čini } \\
\text { xarāxu bui: ene udaxa nada tayilaji ögü̈üle } \\
\text { kemēeqsen-dü: }\end{array}$ & 22 & $\begin{array}{l}\text { Учитель Гууши спросил: «Раскрой мне при- } \\
\text { чину, почему родители тебя накажут и по- } \\
\text { чему учитель станет тебя ругать?» }\end{array}$ \\
\hline 23 & 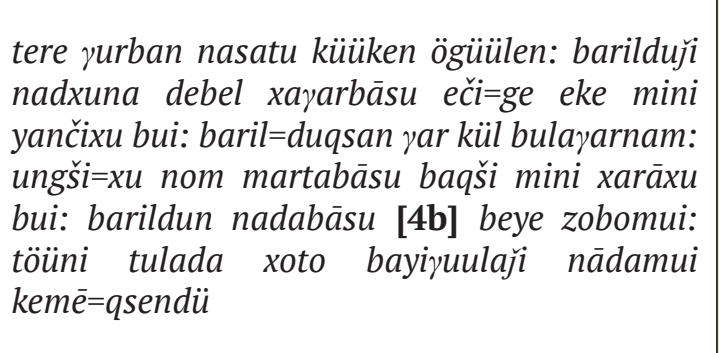 & 23 & $\begin{array}{l}\text { Тот трехлетний мальчик ответил: «Если я } \\
\text { буду бороться, то могу порвать одежду, тогда } \\
\text { родители меня накажут. В борьбе можно вы- } \\
\text { вихнуть руку или ногу. Если забуду про чте- } \\
\text { ние книги, то учитель будет меня ругать. [K } \\
\text { тому же] борьба [4b] приносит физические } \\
\text { страдания телу. Поэтому я играю, строя до- } \\
\text { мик». }\end{array}$ \\
\hline 24 & 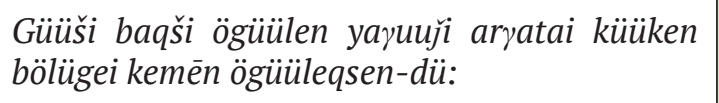 & 24 & $\begin{array}{l}\text { Учитель Гууши сказал: «Ты оказывается спо- } \\
\text { собный мальчик». }\end{array}$ \\
\hline 25 & 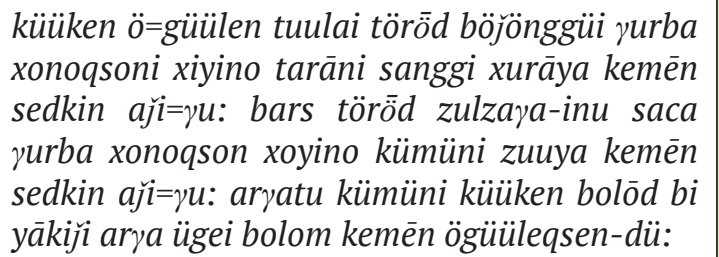 & 25 & $\begin{array}{l}\text { Мальчик ответил: «Зайчонок уже на третий } \\
\text { день после рождения хочет пробовать траву. } \\
\text { Тигренок на третий день после рождения хо- } \\
\text { чет укусить кого-нибудь. Будучи сыном дея- } \\
\text { тельного человека, как мне не быть сообра- } \\
\text { зительным. }\end{array}$ \\
\hline
\end{tabular}

${ }^{1}$ Лу - одно из древних китайских царств, родина Конфуция. Традиционное название современной провинции Шаньдун. 
Güüši baqši ögüülen: ayā küüken namai dayaǰi mini šabi bolxula yambar bui kemēn ögüülebēsü:

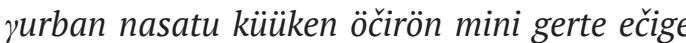
eke axa döü bui: bö=lügē yākiǰi tede bügüde-

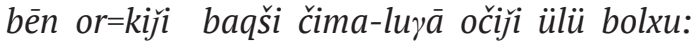
kemēn ögüüleqsen-(dü)

[5a] Güüši baqši ögüülen: mini ter=gen-dü šatār bui: bida xoyor mel=zeldeji šataracaǰ nādaya kemēn ögüüleqsendü

küüken ögüülen: xān kümün šataradu durtai bolxu=la: ulušiyin üyiledü sād genem ajuu: sayid tüšimel kümün šatar-du duratai bolxula

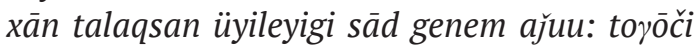

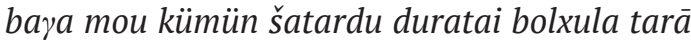
tosoni üyilei-gi sād genem ajuu: toyin xuvaraq kümün šataradu duratai bolxula: nom šaǰini üyiledü sad genem ajuu: tiyimiyim tula bi šataradu duran ügei kemēn ögüüleqsen-dü:

Güüši baqši ögüülen: bi teng=geriyin cagi

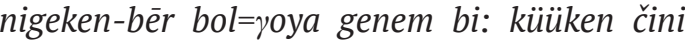
[5b] sanadu yambar bui kemēn öčiq=söndü:

\section{6}

Учитель Гууши сказал: «О, мальчик, что если ты пойдешь со мной и станешь моим учеником?»

Трехлетний мальчик ответил: «Дома у меня отец и мать, братья и сестры. Как же я могу их оставить. Учитель, я не могу пойти с тобой».

28

[5a] Учитель Гууши сказал: «В моей повозке есть шахматы. Сыграем-ка мы с тобой в шахматы».

Мальчик ответил: «Если хан любит играть в шахматы, то это плохо для управления страной. Если чиновники и министры любят играть в шахматы, то это плохо для порученных ханом дел. Если маленький простой поваренок любит играть в шахматы, то это плохо для приготовления еды. Если монахтойн любит играть в шахматы, то это плохо для отправления религиозных дел. Поэтому я не люблю играть в шахматы».

Учитель Гууши сказал: «Я думаю, что небо одно. Мальчик, что ты [5b] думаешь об этом?»

Мальчик ответил: «Учитель, твои слова неверны. Почему ты считаешь, что небо одно? Под небом находится земля, а также океан.

31 Разве каждая из трех в равной мере не наполнена страданием и благоденствием по воле Неба-отца. Учитель, зачем ты говоришь такие слова?»

Пока учитель Гууши, сидел пораженный его ответом, трехлетний мальчик продолжил так: «Если не будет неба, то, как же могут существовать шесть видов существ ${ }^{1}$ ? Если не будет правителя, то, как же может существовать страна и народ? Правитель - основа [6a] народа, земля - основа цветущего дерева, горы - основа для животных, вода - основа для рыб. Так изначально устроен закон бытия. Почему же ты говоришь, что небо одно? Твои слова неверны».

${ }^{1}$ Шесть видов существ (санск. sad jagati; тиб. 'gro ba drug; ойр. zurjān züüliyin amitan) - три вида, обладающих благой участью (тиб. skal-pa; ойр. yurban sayin zayātan): люди, небожители и асуры; три вида, обладающих неблагой участью (тиб. ngang song; ойр. үurban mou zayātan): животные, преты и существа ада. 
Güüši baq=ši udaxā ögüülün: yambar yal utān ügei bui: yambar ere eme ügei bui: yambar eme

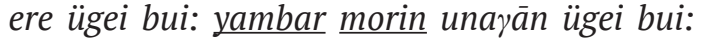
yambur ükür tuүul ügei bui: yambar usun-du

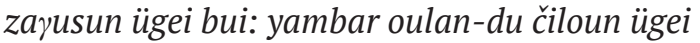
bui: yambar modun-du ündüsün ügei bui: yambar oulan-du gürö= [6b] sün ügei bui: yambar kümün mer=gen sayin aryatai bui: yambar kümüni saca mergen sayin ke=memüi: ene udaxa tayil kemēn ögüüleqsen-dü:
Учитель Гууши сказал: «Ответь мне. У какого огня не бывает дыма? У какого мужчины нет жены? У какой женщины нет мужа? У какой лошади не бывает жеребенка? У какой коровы не бывает теленка? В какой воде не бывает рыбы? У какой горы не бывает камней? У какого дерева нет корня? В каких горах [6b] нет животных? Какой человек считают ловким и находивым? Какого человека называют подобным мудрецу? Дай мне ответы на эти вопросы». yurban nasutu küüken tayilrun: yaltu xorxoidu utān üge=yi bui: toyin kümün-dü eme ügei

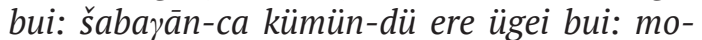

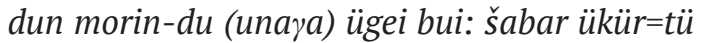

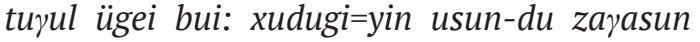
ügei bui: keremiyin oula-du čiloun ügei bui: zurumal modoni kürüqtü ündüsün ügei bui: töyimerdeqsen oula-du gürösün ügei bui: [7a] kid sedkiltei kümüni araya=tai kememüi: čing sedkil=stei erdem yeketei kümün=ni saca mergen sayin kememü=yi kemēn öčiqsön-dü:
Güü=ši baqši basa küüken-ēce asayarun: alini ečige bui: alini eke bui: alini ere bui: alini eme bui: alini örönö bui: alini dorono bui: alini umara bui: boron ali zabsar-ēce oroxu bui: xāna-ēce sal=kilaxu bui: tenggeri yazar xoyoriyin xōr dunda deq=šide kedüi činen xolo bui: kemēn ögüüleqsen-dü

küüken tayi(la)run tenggeri ečige kemēyü: yazari eke kemēyü narani ere kemēyü: sar=ni

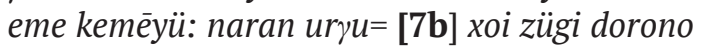
kemēyü: naran šinggekü zügi örö=nö kemèyü: xoyitu zügi umara kemēyü: ömönö zügi ömönö kemēyü: xura ö̈̈len-ēce oro=yu: salkin dali-ēce salkil=yu: tenggeri yazar xoyoriyin xōr dunda dēqšid yesün tümen beri yazar bui: kemēn öčiqsön-dü:

Güüši baqši basa asaүurun: ečige eke ere eme suryaliyin baqši edeni (dotoro) alini amaraq bui ke=mēn asaqbāsu
Трехлетний мальчик сказал: «Жук- светлячок не испускает дыма. У монаха-тойна не бывает жены. У монашки не бывает мужа. У деревянной лошади ${ }^{1}$ не бывает жеребенка, у глиняной коровы не бывает теленка. В колодезной воде не бывает рыбы. У горы с крепостью нет камней. У нарисованных деревьев нет корня. После пожара в горах нет животных. Ловкого человека [7а] называют предприимчивым, человека твердого в своих убеждениях и наполненного знаниями называют мудрым».

Учитель Гууши вновь спросил у мальчика: «Кого называют отцом, а кого матерью? Кого мужчиной, а кого женщиной? Какую сторону называют востоком, а которую западом? Где север, а где юг? Откуда приходит дождь? Откуда дует ветер? Каково расстояние от земли до неба?»

Мальчик ответил: «Отцом называют Небо, а матерью - Землю. Солнце называют мужским началом, а Луну - женским. Сторона восхода [7b] солнца - восток, а захода солнца - запад. Передняя сторона - юг, а обратная - север. Дождь приходит с облаков, а ветер - с моря. Между небом и землей расстояние в девяносто тысяч берег ${ }^{2} »$.

Учитель Гууши спросил: «Кто считается ближе родители, жена или Учитель-наставник?»

\footnotetext{
${ }^{1}$ Деревянная лошадь - инструмент для пыток и наказаний.

${ }^{2}$ Бере (санск. уо̄jana; тиб. dpag-tchad; ойр. berē) - мера длины, равная примерно 14,5 км.
} 
küüken öčirün eme kemēqči üzesküleng=tei $\gamma \bar{o}$ sayin [bolbuču] üre ürǰ̈iü=yin tula türgin zoura amaraq kemēyü: ečige eke suryā=liyin baqši kemēbēsü: teng=geri jazar-tu adali bui: tedkün tējikü bülügē: ye=ke boluqsan xoyino

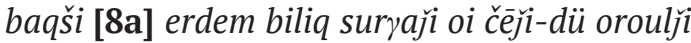

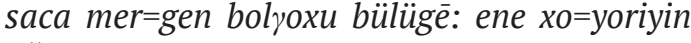
ači ken-bēr tengce=ji ülü bolxu: tere mou eme yākiǰi tengcekü bui:: kemēn ögüüleqsen-dü::

Güü=ši baqši ögüülen eme kemēqči tere nigen derdü derlen nigen debeskirtü keb=ten unta yabun bügü=tölö youni tula ečige eke baqši-èce dutu bolxu bui: kemēn ögüüleq=sen-dü

küüken ögüülen: eldeb züyil modun ö=bösün ündüsün ügei bol=xulā nabči ceceq xamira-ēce delgerekü bui:: ečige eke ügei bolxula: baqši či

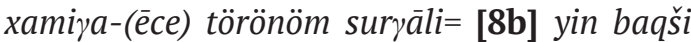


bui: kemēn ögüüleqsendü Güüši baqši sögüdǰi dou ügei soutala:

\section{8}

Мальчик ответил: «Жена хотя и красива, но она близка только на короткое время, ради рождения потомства. Родители и Учительнаставник - растят и опекают подобно небу и земле. По мере взросления [8а] учитель дает наставления и наполняет ум мудрыми знаниями. Ни что не сравнится с этими двумя предпочтениями, как же жена может быть им равной».

Учитель Гууши сказал: «Почему жена, с кототании с родителями и Учителем-наставником?»

Мальчик ответил: «Если бы у деревьев и трав не было корней, то откуда взяться листьям и цветам? Если бы не было родителей, то откуда появился бы ты учитель? Если бы не было [8b] Учителя-наставника, то откуда ты учитель получил бы знания?» Учитель Гууши, преклонив колени, остался в молчании. zurban nas=tu küüken Güüši baqši-ēece xariu


dü douni yeke bui: nuүusun youni-yēn küčündü usuču bui: narsun modun youni-yēn küčündü übül zun ügei kükü-bēr bayičibi baqši či ene udxayigi tayilaji uxuq=daxui kereq kemèqsen$d \ddot{u}$

[Güüši] baqši tayilarun: yaloun kü=zöün urtuyin tula douni yeke bui: nuүusun küliyin alixan örgüni tula usu=či bui narsun modun yol ü= [9a] geyin tula übül zun ügei kükü-bēr bayi(q) či bui: kemèqsen-dü:

[حurban nasutu] küüken öčirün: baqši čini tayilaruqsan üge busu bui: melkei küzöün ügei bolōd youndu douni yeke bui: ongroco kül ügei bolōd youn=du usuči bui: xulusun ši=bēr ebesün kīndöi bolōd youn-du übül zun ügei kü=kübēr bayiq=či bi kemēqsen-dü

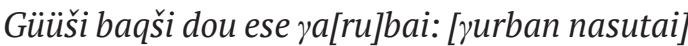

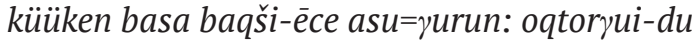
bayiq=či odun kedüi činēn o=lon bui: kemēbēsü:

Güüši baqši ögüülen: yazar dēre=ki yomayigi tōloji čidamui za: tenggeri dereki youmi=gi yākin tōlon medekü: [bi kemēbei:]
Трехлетний мальчик спросил у Учителя Гууши: «В силу чего у гуся такой громкий голос? По какой причине утка так хорошо скользит по воде? Почему можжевельник остается зеленым и зимой и летом? Учитель, ответь на мои вопросы».

Учитель Гууши ответил: «У гуся громкий голос, потому что у него длинная шея. У утки широкие лапы, поэтому она хорошо скользит по воде. У сосны нет сердцевины, [9а] поэтому она остается зеленой и зимой, и летом».

Трехлетний мальчик спросил: «Учитель твои слова не верны. У лягушки нет шеи, тогда почему же так громок ее голос? У лодки нет лап, тогда почему же она скользит по воде? Бамбук полый изнутри, тогда почему же он остается зеленым и зимой, и летом?»

Учитель Гууши ничего не ответил. Тогда трехлетний мальчик спросил у него: «Каково количество звезд на небе?»

Учитель Гууши сказал: «Можно сосчитать, то, 45 что находится на земле, но невозможно посчитать, то, что находится на небе». 


\begin{tabular}{|c|c|c|c|}
\hline 46 & $\begin{array}{l}\text { teyin bö=gösü yazar dēreki gür ulu=šiyin yar } \\
\text { kedüi činēn o=lon bui: kemēbēsü: }\end{array}$ & 46 & $\begin{array}{l}\text { «Если так, то ответь мне, каково количество } \\
\text { рук всех людей, живущих на земле?» }\end{array}$ \\
\hline 47 & $\begin{array}{l}\text { Gü̈üši baq=ši ögüülen: mini geriyin [9b] do- } \\
\text { torki kereqlekü youman-bēn tōloȳi medemüi za: } \\
\text { tere gür ulušiyin yari yākin tōlon me=dekü: [bi } \\
\text { kemēbei:] }\end{array}$ & 47 & $\begin{array}{l}\text { Учитель Гууши сказал: «Можно сосчитать то, } \\
\text { что находится [9b] у тебя дома, но невозмож- } \\
\text { но посчитать количество рук всех людей, жи- } \\
\text { вущих на земле». }\end{array}$ \\
\hline 48 & 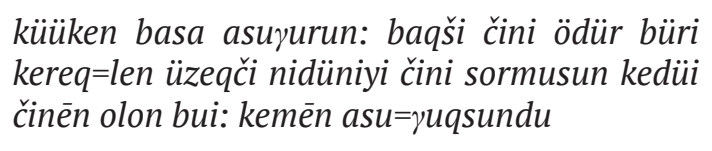 & 48 & $\begin{array}{l}\text { Тогда мальчик спросил: «Учитель, скажи ка- } \\
\text { ково количество ресниц на твоих глазах, ко- } \\
\text { торые ты видишь каждый день?». }\end{array}$ \\
\hline 49 & $\begin{array}{l}\text { Gü̈̈ši baqši ögüü=len: gertēn očid tōloji xoi=ši } \\
\text { ireǰi küüken čimadu kelesü bi }\end{array}$ & 49 & $\begin{array}{l}\text { Учитель Гууши сказал: «Отправлюсь к себе } \\
\text { домой, посчитаю и в следующий приезд, } \\
\text { мальчик, дам тебе знать». }\end{array}$ \\
\hline 50 &  & 50 & $\begin{array}{l}\text { Затем учитель произнес: «Рога, выросшие } \\
\text { позже ушей, вырастают гораздо выше. По- } \\
\text { добно этому и ты. Завтра не говори людям, } \\
\text { что учитель Гууши преклонился перед то- } \\
\text { бой». Сказав так, он сел в повозку, ведя за } \\
\text { собой три тысячи учеников, отправился на } \\
\text { запад. }\end{array}$ \\
\hline 51 & sarva mam gha lam:: & 51 & Да будет благоденствие! \\
\hline
\end{tabular}

\section{Заключение}

Оба произведения, из которых составлен ойратский сборник из фондов Национального музея им. Алдан-Маадыр Республики Тыва, являются интересными образцами литературы народного буддизма. С одной стороны они близки по своей форме, но с другой - отличаются своим содержанием. В первой повести через диалог Будды и брахмана раскрывается суть буддийского закона о причинно-следственной связи всех явлений сансары. Согласно этому закону, причиной всех страданий человека в этом мире являются три неизменные составляющие природы человека - невежество, гнев и вожделение. За добрые деяния следует награда, за пороки - наказание. Кто не совершает греховных деяний, тот не накапливает негативной кармы. Отсутствие таковой помогает избавиться от падения в три низшие формы рождения. Поэтому от страданий можно освободиться только собственными усилиями, рассеяв свое невежество, усмирив свой гнев и преодолев свою привязанность к чувственному миру.

В содержании второй повести мы не найдем буддийских установок. Здесь через диалог Учителя Гууши и трехлетнего мальчика раскрывается традиционная мировоззренческая концепция кочевого монгольского мира - арга билик (метод и мудрость). Арга билиг - это объяснение внутренней сущности вселенной, природы, взаимоотношения человека и природы. В его основе лежит понимание того, что гармония в мире определяется единством и борьбой противоположных начал. Вне этого закона мир существовать не может.

Таким образом, ойратский литературный сборник из фонда Национального музея им. Алдан-Маадыр Республики Тыва является редким образцом письменного наследия ойратов (калмыков), в котором отражены присущие старописьменной ойратской литературе письменные, религиозные и философские традиции. 


\section{СПИСОК ЛИТЕРАТУРЫ}

Билгүүдэй, Г., Отгонбаатар, Р., Цендина, А. Ц. (2018) Дамдинсүрэнгийн гэр музейн монгол ном судрын бүртгэл [Каталог монгольских рукописей Дома-музея Ц. Дамдинсурэна]. Улаанбаатар : ШУА ХЗХ. 620 х. (На монг. яз.)

Ганболд, Д. (2005) «Оюу Чихт хан хөвүүний тууж» тергүүтэн монголын сонгодог уран зохиолын хэдэн дурсхал. Эмхэтгэж, хэвлэлд бэлтгэн, тайлбар сэлт үйлдсэн Д. Ганболд [«История принца Ою Чикиту» и другие избранные памятники монгольской литературы]. Улаанбаатар : ХИС. 113 х. (На монг. яз.)

Очиров, Н. (1910) Отчет о поездке Н. Очирова к Астраханским калмыкам летом 1909 года // Известия Русского комитета для изучения Средней и Восточной Азии в историческом, археологическом, лингвистическом и этнографическом отношениях. СПб., Март 1910. № 10. С. 61-75.

Очиров, Н. (1913) Поездка в Александровский и Багацохуровский улусы астраханских калмыков. Отчет Н. Очирова // Известия Русского комитета для изучения Средней и Восточной Азии в историческом, археологическом, лингвистическом и этнографическом отношениях. СПб. Сер. II. № 2. С. 79-91.

Сазыкин, А. Г. (1988) Каталог монгольских рукописей и ксилографов Института Востоковедения АН СССР : в 3 т. М. : Издательская фирма «Восточная литература». Т. І. 507 с.

Сазыкин, А. Г. (1992) Собрание монгольских рукописей и ксилографов из фондов Тувинского республиканского краеведческого музея им. 60 богатырей (Кызыл) // Тюркские и монгольские письменные памятники. Текстологические и культуроведческие аспекты исследования: сб. статей / отв. ред. С. Г. Кляшторный и Ю. А Петросян. М. : Издательская фирма «Восточная литература». 162 с. С. 45-58.

Санджиев, Ч. А. (2010) Ойратский перевод буддийской притчи «Будда брахман» // Мир «ясного письма» : сборник научных статей / отв. ред. Бичеев. Элиста : КИГИ РАН. 98 с. С. 17-21.

Хонхо (1927) Калмыцкая хрестоматия для чтения в аймачных и в младших отделениях улусных школ : сост. Ш. Болдырев. Вып. ІІІ. Прага : Изд. КККР в ЧСР. 255 с. (На калм. яз.)

Шафрановская, Т. К. (1965) Монголист XVIII века Иоганн Иериг // Страны и народы Востока. Вып. IV. География, этнография, история. М. : Издательская фирма «Восточная литература». 264 с. С. 155-163.

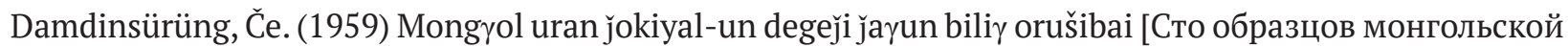
литературы] / Corpus scriptorium mongolorum, Tomus XIV. Ulayanbayatur. 605 х. (На монг. яз.).

Gerelmaa, G. (2005) Brief Catalogy of Oirat Manuscripts Kept by Institute of Language and Literature bu Gerelmaa Guruuchin. Ulaanbaatar : ХЗХ ШУА. 270 р. (На монг. яз.)

Heissig W., Sagaster K. (1961) Mongolishe Handsriften, Blockdrucke, Landkarten / beschrieben von Walter Heissig unter Mitarbait von Klaus Sagaster. Wiesbaden, W. Germany: F. Steiner. 494 p.

Sazykin, A. (1994) Catalogue of the Mongol manuscripts and xylographs preserved in the library of the Tuvan Ethnological museum "Sixty Heroes" // Acta Orientalia Academiae Scientarium Hungaricae. T. XLVII, Fas. 3. Budapest : Academiai Kiado. 467 p. Pp. 327-407.

Uspensky, V. (1999) Catalogue of the Mongolian Manuscripts and Xylographs in the St. Petersburg State University Library. Tokyo : Institute for the Study of Languages and Cultures of Asia and Africa. $530 \mathrm{p}$.

Дата поступления: 30.08.2019 2.

\section{REFERENCES}

Bilguudey, G. Otgonbaatar, R. and Tsendina, A. (2018) Ts. Damdinsurengiyn ger muzeyn mongol nom sudryn burtgel [Catalog of Mongolian manuscripts of the Memorial House of Damdinsuren]. Ulaanbaatar, Mongolian Academy of Sciences 620 p. (In Mong.).

Ganbold, D. (2005) «Oyuu Chixt xan xovuunij tuuzh» terguute`n mongoly`n songodog uran zoxioly`n xe`de`n dursxal ['The Tale of Prince Oyu Chikitu' and other selected monuments of Mongolian literature]. Comp., prep. and comment. by D. Ganbold. Ulaanbaatar, Khovd State University. 113 p. (In Mong.).

Ochirov, N. (1910) Otchet o poezdke N. Ochirova k Astraxanskim kalmy`kam letom 1909 goda [Report on N. Ochirov's trip to Astrakhan Kalmyks in the summer of 1909]. Izvestiia Russkogo komiteta dlia izucheniia Srednei i Vostochnoi Azii v istoricheskom, arxeologicheskom, lingvisticheskom i ètnograficheskom otnosheniyax. St. Petersburg. March, no. 10, pp. 61-75. (In Russ.). 
Ochirov N. (1913) Poezdka v Aleksandrovskii i Bagatsokhurovskii ulusy astrahanskih kalmykov. Otchet N. Ochirova [A trip to Alexanderovsky and Bagatsokhurovsky Districts of the Astrakhan Kalmyks. A report by N. Ochirov]. Izvestiya Russkogo komiteta dlya izucheniya Srednei i Vostochnoi Azii. St. Petersburg. Is. II, no. 2, pp. 79-91. (In Russ.).

Sazykin, A. G. (1988) Katalog mongol'skikh rukopisei i ksilografov Instituta Vostokovedeniia AN SSSR [Catalog of Mongolian manuscripts and woodcuts of the Institute of Oriental Studies of the USSR Academy of Sciences]. In 3 vols. Moscow, Nauka. Vol. I. 507 p. (In Russ.).

Sazykin, A. G. (1992) Sobranie mongol'skikh rukopisei i ksilografov iz fondov Tuvinskogo respublikanskogo kraevedcheskogo muzeia im. 60 bogatyrei (Kyzyl) [Catalogue of Mongolian manuscripts and xylographs housed by the Aldan-Maadyr Tuvan Republican Local History and Lore Museum (Kyzyl)]. In: Tyurkskie i mongol'skie pis'mennye pamiatniki. Tekstologicheskie i kul'turovedcheskie aspekty issledovaniia [Turkic and Mongolian written monuments. Textual and cultural aspects of the study]. Collected papers. Ed. by S. G Klyashtorny and Y. A. Petrosyan. Moscow, Vostochnaya Literatura. 155 p. Pp. 45-58. (In Russ.).

Sandzhiev, Ch. A. (2010) Oiratskii perevod buddiiskoi pritchi «Budda brakhman» ['The Buddha and the Brahmin': an Oirat translation of the Buddhist tale]. In: Mir «yasnogo pis'ma» [The world of Clear Script]. Collected scholarly articles. Ed. by B. Bicheev. Elista, Kalmyk Humanities Research Institute of RAS. 98 p. Pp. 17-21. (In Russ.).

Khonkho [The Bell] (1927). A Kalmyk-language reader for municipal and district level junior schools. Comp. by Sh. Boldyrev. Is. III. Prague, Kalmyk Cultural Committee. 255 p. (In Kalm.).

Shafranovskaya, T. K. (1965) Mongolist XVIII veka Iogann Ierig [The $18^{\text {th }}$-century Mongolist Johannes Jährig]. In: Strany i narody Vostoka [Countries and peoples of the East]. Is. IV: Geography, ethnography, history. Moscow, Vostochnaya Literatura. 264 p. Pp. 155-163. (In Russ.).

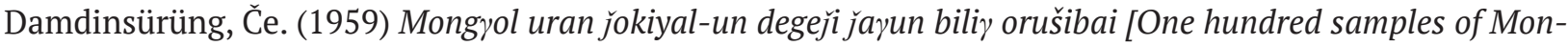
golian literature]. Corpus scriptorum mongolorum, Vol. XIV. Ulaanbaatar. 605 p. (In Mong.).

Gerelmaa, G. (2005) Khel zokhiolyn khürehehlengiin tod üsgiin nomyn tovch bürtgel [Brief Catalog of Oirat Manuscripts Kept by Institute of Language and Literature by Gerelmaa Guruuchin]. Ulaanbaatar, Institute of Language and Literature, Mongolian Academy of Sciences. 270 p. (In Mong.).

Heissig W. and Sagaster K. (1961) Mongolishe Handsriften, Blockdrucke, Landkarten [Mongolian manuscripts, xylographs and maps]. Descr. by Walter Heissig and Klaus Sagaster. Wiesbaden, W. Germany, F. Steiner. 494 p. (In Germ.).

Sazykin, A. (1994) Catalogue of the Mongol manuscripts and xylographs preserved in the library of the Tuvan Ethnological museum "Sixty Heroes". Acta Orientalia Academiae Scientarium Hungaricae, vol XLVII, is. 3, pp. 327-407.

Uspensky, V. (1999) Catalogue of the Mongolian Manuscripts and Xylographs in the St. Petersburg State University Library. Tokyo, Institute for the Study of Languages and Cultures of Asia and Africa. 530 p.

Submission date: 30.08.2019. 